\title{
Ethnic Diversity as Tool of Good Governance in Nigerian Political Dialectics
}

\author{
Chika J. B. Gabriel Okpalike \\ Department of Religion and Human Relations, Nnamdi Azikiwe University, Awka, Nigeria \\ Email: cg.okpalike@unizik.edu.ng
}

Received 14 May 2015; accepted 16 June 2015; published 19 June 2015

Copyright (C) 2015 by authors and Scientific Research Publishing Inc.

This work is licensed under the Creative Commons Attribution International License (CC BY). http://creativecommons.org/licenses/by/4.0/

CC) (i) Open Access

\section{Abstract}

The principles of Good Governance presume peoples, nations, systems, corporations, cultures and so forth. These entities are what must be found at the backdrop of a possible Good Governance in Nigeria. Meanwhile the collapse of any civilization; the decay of any society; the death of the human spirit in any epoch is often heralded by the deterioration of culture. In other words anarchy in and disintegration of any society are consequent upon a decline, decadence, misconstrue or neglect in the culture of that society. Identifying the veritable Nigerian culture is a task outside whose accomplishment Good Governance in the country remains a farce, because it is a people who generate culture and a culture which grounds Good Governance. The quest for Good Governance in Nigeria is a pipe dream; a flight of fancy in as much as the Nigerian people is phantom and their culture inanity. Meanwhile it is more convenient to talk about the people, culture, language and religion of Nigeria in plural terms. Therefore we can only say Nigerian cultures, languages and religions. It was John S. Mbiti [1] and Emefie I. Metuh [2] who had agreed on this plurality only in terms of African Religions. Plurality as diversity is the essential character of Nigeria. We may conveniently talk about the Igbo (Likewise Yoruba, Hausa, Kalabari, Ogoni, Ibibio, Tiv and so on) culture, language, religion, people and so forth. Yet even at that, what we mean can easily identify with the past and dying ways of the people which the present recalls according to the strength of their hindsight, but which has no relevance at all on the life of those who commemorate them. This article from a phenomenological perspective understands culture as a unified way of life that binds a people together and identifies its absent presence in Nigeria with the inevitable consequence of the illusiveness of Good Governance. It then opens the vistas of another possibility of building Good Governance on the same diversity.

\section{Keywords}

Good Governance, Tribal Nation, Nigerian Tribes, Cultural Diversity 


\section{Introduction}

The state of affairs of the Nigerian nation since independence had been characterized by instability, insecurity, suspicion, violence and crisis at every stage of its national development. The events that led up to the present time when the nation is almost at the brink of breaking up are filled with litany of issues which pointed to this moment in history with unerring accuracy. As it were, the regions that were amalgamated in 1914 by the efforts of Lord Fredrick Lugard began on time to show signs of disintegration. By 1957, it was clear that there existed a chasm between the North and the South in their understanding of independence and the need to struggle for that most coveted price in Africa of that period. Thus began negotiation for concessions and compromises; with emphasis on the "we" and "them"; the "we" representing each ethnic group emphasizing its autonomy from the 'them' which represents the rest of the ethnic groups. In other words the autonomy of every individual ethnic group featured prominently in the pre-independent Nigeria. Before independence, therefore, regional consciousness had already been created in the psyche of the people and their self-determination hugely informed by this consciousness. At independence, the British were ready with the amorphous and loosely knit nation in the name of Nigeria, made up of strong regions charged with ethnic consciousness each drawn apart as in a combat for a loot, even then Britain declared its independence on October 1, 1960. Only six years was going to elapse before the dynamite detonated and ignited a crisis that culminated into the bloodiest war and genocide in Africa of that period. Up till the present day, the ship of Nigeria is still rocking in the sea of British troubled waters. From a purported Igbo quest for domination resulting in a mindless pogrom to Biafran secessionist struggle; from military totalitarianism to military despotism and tyranny; from the riots of the Oduduwa Peoples' Congress (OPC) to the unrest of Arewa Consultative Forum (ACF); from the insurgence of the Movement for the Actualization of the Sovereign State of Biafra (MASSOB) to the awakening of Movement for the Survival of the Ogoni people (MOSOP); from the resistance of Niger-Delta militants to the terrorist attacks of Boko-Haram. The Nigerian nation has surely become a wreckage of multiple crises. Evidently, all the sections and factions of this country have cried out in disagreement to this Nigerian entity; not because they cannot exist together or side-by-side each other but because the foundation of the nation is faulty and something needs to be done about it. Several attempts had been made in the past to bring together the diverse sections of the Nigerian nation to a table of unity, understanding and consensus, but none produced that desired result which should kick-start a nation peopled by persons of common faith, value and destiny at least in terms of the nation. Worthy of note is that the former President of Nigeria Dr. Goodluck Jonathan began again the convocation of a CONFAB in his Independent Day speech of October 1, 2013. That conference has sat, compiled and handed over its submissions which that administration was not able to implement but handed over to the current Muhammadu Buhari administration. May be as it has been in past times, nothing may be heard of it in future. What is clear from this piece of History is that the voices of the regions are stronger than the voice of the nation, the passion for survival and co-existence is stronger and more formidable in the regions than at the national level, and the supposed people of Nigeria are primarily a regional people. Another strong area is religion; most times Nigerians do not want to mention it. Religious affiliations form the principal character in determining the personhood of the African, nay Nigerian. To constitute Nigeria, there is need for the regions to come together in whatever manner and stipulate conditions and modalities. That will be the beginning of a journey to build a culture which will be called Nigerian. Before then, this article contends the existence of any culture that could be properly called Nigerian and evaluates the common Nigerian way of doing things as a culture rather degrading of human dignity. In other words, the Nigerian culture is both present and absent. It is present in a sense that there is a consistent Nigerian way of doing things which could be seen in everything Nigerian and absent in a sense that a Nigerian culture cannot begin to emerge when Nigeria itself is a wishful thinking; when the component parts of the country still exist as if Nigeria is one common enemy faced by each in its regional consciousness. This writer is of the opinion that good governance should be founded on a veritable culture and it is improper to talk about good governance in the absence of culture.

In the face of this reality, Good Governance presents as the ultimate solution to the Nigerian problematique if we heed the verdict of Chinua Achebe who identified the problem of Nigeria with leadership [3]. Even as we do not presume that good governance and leadership are synonyms, at the same times the boundary that separates them is but a hairs breath. To the present writer, this can only be true when the rest of the Nigerian populace have given up the struggle to nationhood and are resting on their oars for the so-called leaders to either solve the Nigerian equation or call the first shot to its solution. Otherwise the submission of Arthur Nwankwo is invaluable: 
The health of a body politic depends on the capacity of leaders and citizens alike to learn from past mistakes. What lessons have Nigerians learned from their chequered history since independence in 1960? To what extent has Nigeria matured in its aspiration to greater nationhood? [4]

Arthur Nwankwo meant that the solution to the Nigerian problem lies in the hands of the leaders and people alike via lessons from the mistakes of the past. Even in that submission, Nwankwo took it for granted that the Nigerian nationhood had been achieved, only that the nation is in a striving to achieve "greater nationhood". Again the present writer thinks that the problem with Nigeria is more foundational than those presented by the opinions of Chinua Achebe and Arthur Nwankwo. This writer locates the Nigerian problem as foundational; lying beneath the composition of a state destined to fail. It was an Act of the British Parliament that composed the Nigerian state and beyond that declaration, the various parties that constitute the entity have not come together to state their common interest, struggle and destiny upon which they freely decide to submit their individual wills to a collective will of the Nigerian state. This beginning will surely constitute a people and mark the beginning of the building of the Nigerian culture. It is this people and culture that will produce good Nigerian leaders assessed by the standards of the nation's collective interest.

\section{What Is Culture?}

Culture could be viewed from one of three perspectives:

- Excellence, ideal or class of taste in fashion, art or etiquette.

- An integrated and consistent pattern in learning, behavior and belief.

- A set of shared attitudes, values, goals, beliefs, practices that characterizes an institution, organization or society.

Even in these, what is the Nigerian culture that could be found? By Nigeria we do not mean a geographically marked out West African country, bordering the Gulf of Guinea, between Benin and Cameroonand located $10^{\circ}$ North and $8^{\circ}$ East; having a population of over one hundred and sixty million $(160,000,000)$ people. When we say Nigeria we mean a nation; a people with one faith, aspiration and destiny; an entity that contains together and accommodates all its citizens; in which its concern is one for all and all for one. In other words, if Nigeria is viewed as such a nation, what may be in reality outlined as its culture within the boundaries of the definitions stated above? Yet troubling is another aspect of culture not represented above but was given in Mark Rosenfelder's Metaverse in an attempt to reply to the objection "no such thing as American culture". He defined American culture as "things shared by the vast majority (let's say 90\%) of native-born Americans... they will sound like just descriptions of the way things are.” [5] This is rather more a phenomenological approach to the definition of culture and seems to reply immediately to the objection of the subject of this article. This approach impresses that culture need not be a deliberate consensus agreed upon by a majority of the populace, preserved and transmitted from one generation to another, yet it is a regular and consistent pattern in the responses of a people to the challenges of their existence mutatis mutandis; the conscious and unconscious responses given by the people at various times to issues confronting their lives. It is ever evolving; taking shape consistently in a regular pattern.

Consequently, knowledge of culture in its particularity is a posteriori; it depends on experiential and observable behaviours and patterns. The culture of a people is written in their life-patterns and reflexes; they are those data upon which is based the predictability of a people's responses to issues and situations. If these assertions are right then the present writer opines that materials about Nigerian culture always tend to say either of two things-that Nigeria has no culture or that the Nigerian culture has not been succinctly and sufficiently outlined and dealt with. This statement will certainly appear curious and unacceptable to quite a number of people. Yet it does not seem that this writer is alone in this kind of thought. Tim Curry in an attempt to suggest reasons for the scantiness of Nigerian symbols reasoned: "Because there is little feeling of national unity among Nigeria's people, there is little in terms of national symbolism.” [6] This statement may not be wished or shoved away in a hurry. Symbols, like language and values, are core components of culture. In other words, these bespeak the culture of a people. Therefore the scantiness of symbols itself symbolizes the scantiness of culture. In fact apart from the national flag, anthem, pledge and coat of arm, there does not seem to be any other symbol of the Nigerian nation. Nevertheless we can find monuments, structures, spaces and institutions which are constructed to express nationhood and unity; not without being impregnated to bring out one of many silent dimension of the 
unspoken Nigerian culture. By this we mean, that which is shared by majority (say 90\%) of native-born Nigerians in the actual day-to-day life. This falls in line with the position of Dennis O’neil:

While human societies and cultures are not the same thing, they are inextricably connected because culture is created and transmitted to others in a society. Cultures are not the product of lone individuals. They are the continuously evolving products of people interacting with each other. Cultural patterns such as language and politics make no sense except in terms of the interaction of people. If you were the only human on earth, there would be no need of language or government. [7]

According to this position, whatever is seen in the politics and government of Nigeria is understood as the Nigerian culture. It is by reviewing what has transpired in the area of politics in Nigeria that the ingredients of the Nigerian culture may be seen. Predictably what shall be seen thereof falls short of the basic required behavioural patterns that may enhance human life; a culture that has held its people in captivity for more than half a decade; a culture that may be likened to a cacophony emanating from the discordant notes of the Nigerian political orchestra which rather stampedes the Nigerian sense of harmony with divisiveness and dichotomy.

Beyond this, what most often poses as culture in Nigeria belongs to the tribes or ethnic groups. Furthermore, these so-called cultures are mostly understood as a people's dressing, arts, religion, dances, food and ceremonies which are often reminiscent of the past. Therefore whenever culture is mentioned, Nigerians think about exhibiting, showcasing and representing. Culture becomes that which we dramatize as our regional identity and that which connects us to our tribal or ethnic past. Even when these externalities are transcended into values and morals, their strength and effects are both binding and sustainable in the regions that it reflects. We are rather interested here with patterns which could be categorized as a national identity. This pattern could be seen in the socio-political sphere and the manner of addressing our common interests.

\section{The Nigerian Dialectic of the Tribe and the State}

Aristotle is at the basis of the understanding for which the tribe has come to take on the quality of savage, primitive, barbaric and so forth. The great philosopher understood the building of human society through the stages of the individual, family, clan, tribe to nation or state. According to this idea, the tribe is a moment in the constitution of a state and the state is the apex and finest of human society. Barnabas Okolo observes that the consequences of this Aristotelian position is that the state is where man can live and exercise his full potential while the tribe falls short of the ideal for man and can only be appreciated as a stage in the development of a state [8]. Interestingly, the term tribesman or tribal peoples have come to be the identity of Africa and other developing nations in any socio-political discourse. As such, tribalism is regarded as a crime even to the magnitude of arson and felony. William F. Buckley even equated tribal struggles in Africa with racism [9]. Ebenezer Babatope (1981) is of the opinion that most coups in Africa is as a result of “tribal wrangling” [10]. Okolo (1993) identifies tribal struggles as the foremost social evil in Africa and succinctly avers:

Notwithstanding the change of names of many African nations since independence, the basic structure of their ethnic composition has remained the same and the basic problem it engenders in practical life has not diminished either. The common terminology of this problem as an unsettling domestic evil is tribalism. [11]

Chinua Achebe understands tribalism as “discrimination against a citizen because of his birthplace” [12]. Even this definition is wrong in the Nigerian context because "birthplace" in Nigeria doe not contribute to ones identity; descent is the key to understanding tribalism in Nigeria and indeed Africa. The truth is that the African can easily identify as a tribesman more than he can identify as a citizen of a state. In the first place, the idea of state in Africa is the creation of Europe which does not take cognizance of tribal differences and affinities. Secondly the structures of the state; its hierarchies and operations are in utter defiance to the structures of African traditional society so that the idea of the sacred and sacrosanct as they have to do with order in society is seriously mutilated. This Aristotelian idea of the development of the state either does not square up with the people and situation of Africa or did not take into account the important component of the African society like the tribal patterns. There is no doubt that the peoples of Africa can only be categorized according to their tribes. There is nothing wrong with the Aristotelian theory of the formation of nation-states. Rather it is simply clear that Europe failed to understand that those nation-states must be founded on the superstructures of the tribes. 
Once Europe missed that point in the formation of African states, it was faced with the challenges of the survival and sustenance of tribal ties. To deal with that challenge, it paved the way for tribal struggle to be understood as a social evil. One of the major characters of an independent nation is self-determination and this character is what was absent in most post-independent African states. The plans of those states that attempted it were scuttled by the European check in the name of neo-colonialism often couched in financial aids and socio-political interventions. It is not that the European nations were not as much tribal as Africa but that the society evolved from within through time and took its shape. Africa had traditional structures for such evolution which were dismantled by this European political arrangement. As a result of this, the African nation became a maneuvered manipulation of Europerid of agents of evolution.

In Africa, it is the tribe that has the language, culture, history, tradition, religion and social institutions. In Nigeria, these components of the tribe are still very strong in spite of British colonial arrangements. Remarkably, the idea of three major tribes in Nigeria did not survive the thirty months civil war that lasted till January of 1970. Before that war, it can easily be said that there are three tribes in Nigeria—Hausa, Igbo and Yoruba-but the Igbo tribe did not exercise as much dominance in the Eastern Region as did the other tribes; Hausa in the Northern Region and Yoruba in the Western and Mid-Western Regions. Meanwhile the creation of the Mid-Western Region out of the Western Region was inspired by the scheme to divide loyalty to Yoruba dominance; the same scheme was to be employed in 1967 by Yakubu Gowon in the creation of twelve states to disintegrate the Eastern Region. The resistance to this scheme as he warned in his national broadcast of May 27, 1967 brought about thirty months of civil war and bloodshed. Yet even that resistance could not allay the scheme because it was the propaganda of the illusory advantages of this disintegration for the minor tribes of the East Central State believed by the leaders of the now Niger-Delta that contributed immensely to the loss of that area by Biafra and the eventual decline of their agitation for an independent state. Up till now the effect of that propaganda still has its toll in intra-tribal relations. For instance, even when the Ikwerre, Ika-Igbo and others retain a language and culture that is characteristically Igbo, they create and sustain a consciousness, illogical and weird as it seems, that they are not of the Igbo extract. Even at that, in the various states of the federation, where couples of these minor tribes are clustered-Rivers, Bayelsa, Cross-River, Delta, Edo, Benue, Kwara, Adamawa and so forth—politics of tribal dominance and subjugation still thrive.

All these go a long way to say that in Nigeria, tribal fraternity is stronger than national unity; sectional interests attract more dependable and credible loyalty than national programs. The average Nigerian is more at the tribe than the nation. For quite a number of people, there is more dignity in a tribal role than a national role and tribal roles demand more commitment and character than national roles. Most people will not feel fulfilled as having contributed to the society until such a contribution has been recognized by the tribe especially through some offer of traditional cultural titles. The formation of political parties in Nigeria are along tribal lines to promote tribal interests except in recent times when intra-party structures more than the parties themselves are informed by tribal interests. Analyzing the politics of the early days of the second republic, Richard A. Joseph (1999) writes:

Many observers were surprised at the familiar nature of political alignments which surfaced with the lifting of the twelve-year ban on political parties in Nigeria in September, 1978. Of the five parties which were granted legal status, four of them, the NPN, NPP, PRP, and UPN, could be shown to have clear links with the former dominant parties of the independence era. Moreover, the pattern of votes demonstrated that considerable ethnic consolidation had taken place in support of the second and third strongest parties, the NPP and UPN, involving two sections of the population whose inter-dynamics have constituted so much of the background to Nigerian political events since the 1940's, namely the Igbo and Yoruba peoples. [13]

It must not go without saying that one of the break-through of the second republic was its ability to form a political party which harmonized to some extent the conflicting national and sectional interest that has characterized Nigerian politics. That party is the National Party of Nigeria (NPN) led by Alhaji Shehu Shagari. That party is the precursor of the contemporary People's Democratic Party (PDP) and both reserve the reputation of dominating Nigerian politics at the national level. Nevertheless intra-party structures still took care of the perennial sectional interest in Nigerian politics and aggrieved individuals who feel that the interests of their section are not adequately served by the party are always seen on the run and forming parallel parties as opposition. It was the PDP which came up with the policy of "Zoning” which has almost unofficially become a national pattern of political and civil arrangement. Zoning simply means a pattern in which the various sections of the country 
known as "Geopolitical zones" which is a political replacement of the former "Regions" (all constituted along tribal lines) take their turns in the leadership of the country. This arrangement is intended to make for the possibility of all the sections of the country to participate in the national life one time or another. Although the result of the 2015 elections would seem to have broken this PDP myth of domination, yet it is clear that a SouthWest/North-West (rendered in local parlance as Hausa/Yoruba) alliance together with the spill-over from the PDP over-burdened concentration contributed immensely to the success of the All Progressive Congress (APC) which today has clenched the federal government. From whatever perspective one can look at it, it is sectional interest which drives Nigerian politics and every politician has it at the back of his or her mind that the success of a political career is determined by the extent to which the interest of one's section of the country was served during that period.

Evidently, the Nigerian political culture in retrospect and in practical terms is a collection of varied nuances of regional, ethnic and tribal struggles in which the centre is looked upon as a mass of carcass to scavenge. By extension, the Nigerian people get into politics primarily to better their personal and tribal lots; the wellbeing, development and progress of the nation and the people of the nation are secondary. This culture is so endemic in the system that everyone is compelled by its lures; even the most upright of Nigerians is saddled with the burden of the Nigerian edifice constructed upon this foundation. Consequently, anything national in Nigeria is understood as a battleground, chimerical monstrosity fought from the formidable armories of the regions, enemy of all those regions whose kiths and kin are not present at the center, free looting zone, and so forth. From the national level, this culture extends even to the regions themselves. In intra-regional matters, this Nigerian dynamism is replicated in a micro scale. In summary, government in Nigeria is a British legacy of exploitative imperialism aimed at enriching its operators and impoverishing the nation and people. Sadly enough good governance is unofficially defined along these lines. Whether or not this situation of things soothes the Nigerian people or enhances their lives is not the judgment of this article; but the status quo as exposed speaks the political culture and idea of governance in Nigeria.

\section{The Nigerian Dialectics of Civil and Traditional Society}

The American anthropologist Alfred L. Kroeber is of the opinion that society precedes culture; he even went as far as saying that there can be a society without culture [14]. Kroeber simply meant that society precedes culture secundumfiari; it is only a human society that can generate and sustain culture. Culture is generated from the society which it defines and is one of the instruments with which the advancement of a society is measured. Culture mirrors the norms, values and ethics of a society and these depict the advancement of the human spirit in that society. M. Angulu Onwuejeogwu faults Technology as the criterion of evaluating the advancement of society [15]. In other words the idea that nearness or farness to it determines how advanced a society is. In doing this, he rejects the idea of evolution propagated by the western world as the process of the development of society and contends that even the word primitive may not be used to describe whole societies and cultures but aspects of them. In line with these thoughts of M. A. Onwuejeogwu, the modern period of European history witnessed the height of the development of human mind which in our time in spite of technology is at its lower ebb.

The word "Civil" oftentimes implies the advancement of society beyond its natural and traditional dynamism. The word derives from the Latin "Civilis" or "Civis" which simply means "of the state” or "the state”. So, civil society is a society that has attained statehood; the kind Aristotle had posited. Anderson and Taylor (2004) defines the state as "the organized system of power and authority in the society" [16]. To underscore the implications of the existence of a state for human society, it further declares:

The state is an abstract concept that refers to all those institutions that represent official power in society, including the government and its legal system (including the courts and the prison system), the police, and the military. The state regulates many societal relations, ranging from individual behavior to interpersonal conflicts to international affairs. [16]

In this same vein, Oliver A. Onwubiko (1991) describes the term 'Community' in African understanding thus:

The community is the custodian of the individual, hence he must go where the community goes. In the material terms of reference, the individual must go to the "community centre" or village square which is the social, political, judicial and religious centre. It is the communal meeting place for political discussions, 
communal tribunals, sports and games. [17]

The two ideas above represent the dynamics in a civil and a traditional society. Remarkably, there are no contradictions in the constitution of both entities. It is then curious why those two entities seem to be in insoluble conflict in Africa and especially in Nigeria. Western sociologists and anthropologists always present African peoples and systems as primitive and savage. Unfortunately, many of them (Africans) who are western trained do not seem to see any problem with this western position on Africa. The source of the conflict is clear. The structure of the African civil society cared nothing about African sensibilities and is not constructed for the good of Africa. Otherwise the so-called statehood or nationhood is not opposed to traditional structures. Such 'abstract concept' could be made real by creating enabling environment for dialogue among the diverse regions of the nation. But that would not be, since the conflict that resulted from the forced marriage called Nigeria was well-intended by the initiators of that bond and their gain is sustained by that conflict.

As in the first dialectic, state and tribe, so in the second, civil and traditional; while the state takes on the quality of civil so does the tribes take on the quality of traditional. The present writer is of the opinion that culture is the crux of the matter. How may culture be generated and sustained if the Nigerian entity is in disarray? On the other hand, even when the conditions are not met for the emergence of culture, the dynamism in the nation's life; officially accepted or not; officially endorsed or not, amounts to culture. It is that dynamism that could be found that the present writer understands as the veritable Nigerian culture upon which good governance could be built. They include tribalism, nepotism, sectionalism and dichotomy. These ingredients of Nigerian culture have openly been celebrated through the years but the nation keeps pretending that they are some kinds of problem we needed to conquer. To conquer them is the same as undermining the Nigerian moral stronghold; to continue to discredit their positive values is to deny the very ingredient of national development. In as much as that has not been done; in as much as these keep being relegated at the background of corruption then Nigeria is a society without a culture and there cannot be a possibility of good governance.

\section{The Nigerian Foundations of Good Governance}

\subsection{Tribalism}

It was Oliver A. Onwubiko (1991) who had advocated for a re-evaluation of tribalism, and warned against a possible ethnocide schemed by those who propagate ethnic neutrality as a means of solving the problem of tribalism. He asserted the invincibility of ethnicity and tribalism in African socio-political life when he predicted:

A re-evaluation of tribalism is urgently called for to avoid the more dangerous consequences of the now powerful political tribes which are everywhere but not located anywhere-tribes in which there are neither permanent friends nor enemies. [18]

Already this amorphous political tribe is rearing its head in Nigerian politics as the People's Democratic Party (PDP). This party like the former North has come to understand ruler ship of this country as their birthright. Members of the party who aspire to one office or another simply see it as taking turns because everything has been arranged in a calendar with individuals ear-marked for what they may when they may. If the members of that party have an option, they will turn the country into a one-party state bothering nothing about its consequences. Yet this political party like others has no political ideology it propagates; no political theory it advocates. Whatever its program is informed by loyalties to interest groups and affiliation to tribes. In Nigeria, the blood of ethnicity and tribalism is thicker than the bond of nationalism. Consequently, tribalism should be the bedrock of Nigerian socio-political arrangement accepted by our legal system; its modus operandi can be worked out. It could be re-defined to mean a socio-political concept which advocates the supremacy of tribal interests as a means of achieving the objectives of a sovereign state. It can be defined in terms of number or Gross Tribal Contribution to the national treasury. Rwanda is a typical instance of an African nation where detribalization was pretended. The Hutu and Tutsi lived side-by-side each other as good friends and neighbours for years till the dawn of April 6, 1994 when the pretence had to give way to reality. The genocide that followed that awakening claimed about eight hundred thousand $(800,000)$ Rwandan lives. The rancor that led up to the carnage of Rwandan genocide did not happen in a day; it had to take years of bottling-up anger generated by working for an elusive tribe (the nation) and down-playing the power of ethnic bond over above national unity in Africa. 


\subsection{Nepotism}

Jude Uwalaka (2003) is among the advocates of the conquest of tribalism and nepotism. The silent paradox of his expositions is that they are endemic in our socio-political and economic system:

Unfortunately it appears that it is these legacy of skepticism, divisiveness, tribalism, nepotism and religious and ethnic bigotry that have endured, and for all intents and purposes, Nigeria has remained a political space, with no true national identity, no national consciousness, no national commitment and no true national loyalty. [19]

While J. Uwalaka is equipped with the correct information about the Nigerian situation, it remains for him to be imbued with the consciousness that he is face to face with the essential structure of Africa nay the human race. How many countries in Europe are as large as Nigeria? In their territories they formed their modern states in the pattern of their tribes but when our tribes fight the subjugation that detribalizes them, it is called tribalism and is given a negative meaning. Detribalization amounts to depersonalization. The tribe is the source of personhood. According to Odimegwu (2007):

African communalism is generally projected as the theory of African social existence in which the individuality of the person is founded on his communality. The person in this theory is basically a communal being and the evaluation of the authenticity of personal existence is undertaken via the fundamental principles of communal existence. [20]

The African is basically a tribal person and it is from the nature of this person that the idea of a nation emerges. One may make bold to say, no matter how small Nigerian tribes, it would not be abnormal if the Anang, Ibibio, Efik, Ogoni or Kalabari becomes a state in Nigeria. A critical look at Africa will clearly pose the fact that European arrangement of African nationhood is an attempt to rip Africans of the cultural blood ties which gives them vitality. This cultural blood ties is the basis for Nepotism. Nepotismis a criterion of judgment or doing things based on blood ties. No matter the extent to which the practice is alarmed, the African leader cannot see any problem in awarding a contract to his less qualified relative than a better qualified stranger. Of course the reason is clear. His suspicion is allayed; his confidence strengthened at the thought that his blood relation is involved. The advocacy of this article is that there would be no point fighting it or pretending about it because the next leader who is speaking against it just did it before the speech.

\subsection{Sectionalism}

This could also be referred to as "Regionalism". It simply means the struggle of a part of the nation to impose its interest on the rest of the nation or the supremacy of sectional interests. In Nigerian politics, people want to hear how a particular office holder/aspirant will serve their sectional interest. The South-Easterner will want to hear that the second Niger Bridge will be built and the River Niger converted to a seaport. The South-southerner will want to hear that the region will be made to have more control on oil. Merely saying that ignites their political affiliation towards whoever says it. The political idea is that when the region benefits it is the nation which benefits. Every legislator convinces his/her section of the country of his/her qualification to represent them by how well he/she defended his/her ability to get their own share of the national cake home to them. They need to be convinced that their political decision is of maximum advantage to them. Nobody connects with the voters by discussing issues of national interest or by bringing the nation into the picture of things to be done during the term of his/her reign [21]. These go a long way to say that the nation is inadvertently interpreted through the prism of the sections. In other words the Nigerian people are basically people of sectional loyalty and are averse to issues of national interest. Sectionalism could be solved by giving the sectional relevance that our situation demands. Knowing full well that:

When the British arrived these parts, they met, and dealt separately, with that various communities that now form the Republic of Nigeria. These communities, though aware of the existence of one another, each developed its own civilization independently and retained absolute autonomy in all sphere of human activity. [22]

It is possible to make a nation out of Nigeria only when the nation is seen as a confederation of autonomous republics. Through that structure what used to be of negative influence in the socio-political life of the nation 
will become strength.

\section{Conclusion}

This article has tried to articulate the Nigerian socio-political culture upon which good governance could be founded. In the first place, the position of this article that Nigeria has no culture is sustained by the truth that culture in Nigeria most times belongs to the ethnic groups; they are celebrations and reminiscence of the past of our various tribes. Culture most often is not an attribute that is given to Nigeria as a nation except in cases where a couple of the tribal cultures are referred to as Nigerian cultures. In the second place, there are ways of doing things in Nigeria whose frequency and consistency could add up to culture according to the definition of Mark Rosenfelder [23]. Yet those ways are given very negative interpretations that no Nigerian will be proud of it in spite of the truth that it is the normal way of life; tribalism, for instance. Beyond the conventional ways of looking at those manners of doing things, this article held that they are born from human nature and African culture and may not be easily eradicated in the lives of Nigerians. Nothing may be wrong with them after all if Nigerians were to disrobe themselves of the garb of western mentality. Africans and Nigerians should proudly be a tribal people; understanding that there is nothing wrong with that. They should accept and adopt their natural conformity to the logical correspondence of blood ties which cannot be obliterated or replaced by the coherent logic of rational concepts; adapt, improve on and make the best out of it. If in course of this amorphous and forced co-existence the Nigerian people recognized their tribal differences and set up institutions like the Federal Character Commission then they can use the tribe as a platform for fair competition at individual and corporate levels; through it encourage productivity and excellence in spite of the tribal platform to culminate in the development of the state/nation. The aim of good governance is to maximize both the impact and the reach of the impact made in the lives of people by the machinery of governance. In order to do that, the system has to be set in such a way that it could check itself. The tribe is the most effective check. No tribesman can evade the check of his tribesmen; he knows that he comes from them and owes them account for whatever he does on their behalf. The tribe is the foundation of good governance in Nigeria and should be adequately employed to make the lives of all Nigerians better.

\section{References}

[1] Mbiti, J.S. (1975) African Religions and Philosophy. Heinemann Publishers, London.

[2] Metuh, E.I. (1987) Comparative Studies of African Traditional Religion. IMICO Publishers, Jos.

[3] Achebe, C. (1983) The Trouble with Nigeria. Fourth Dimension Publishers, Enugu.

[4] Nwankwo, A.A. (1980) Nigeria: The Challenge of Biafra. Fourth Dimension Publishers, Enugu, 9.

[5] Rosenfelder, M. (2015) How to tell if you are American. The Metaverse. http://www.zompist.com/amercult.html

[6] Curry, T. (2006) Nigeria. Countries and Their Cultures. http://www.everyculture.com/Ma-Ni/Nigeria.html

[7] O’Neil, D. (2006) What Is Culture. Human Culture: An Introduction to the Characteristics of Culture and the Methods used by Anthropologists to Study It. http://anthro.palomar.edu/culture/culture_1.htm

[8] Okolo, B.C. (1993) African Social and Political Philosophy. Fulladu Press, Nsukka.

[9] Buckley, W.F. (1974) Racism in Black Africa. Toronto Sun (April 6).

[10] Babatope, E. (1981) Coups: Africa and the Barracks Revolts. Fourth Dimension Publishers, Enugu.

[11] Okolo, B.C. (1993) African Social and Political Philosophy. Fulladu Press, Nsukka, 77.

[12] Achebe, C. (1983) The Trouble with Nigeria. Fourth Dimension Publishers, Enugu.

[13] Joseph, R.A. (1999) Democracy and Prebendal Politics in Nigeria. Cambridge University Press, Cambridge, 44.

[14] Kroeber, A.L. (1953) Anthropology Today. Cambridge University Press, Cambridge.

[15] Onwuejeogwu, M.A. (2007) The Social Anthropology of Africa. Heinemann Publishers, Ibadan.

[16] Anderson, M.L. and Taylor, H.F. (2004) Sociology: Understanding a Diverse Society. Thompson Learning Inc., Canada, 528.

[17] Onwubiko, O.A. (1991) African Thought, Religion and Culture. SNAAP Press, Enugu, 14.

[18] Onwubiko, O.A. (1991) African Thought, Religion and Culture. SNAAP Press, Enugu, 21.

[19] Uwalaka, J. (2003) The Struggle for an Inclusive Nigeria: Igbos: To Be or Not to Be? SNAAP Press, Enugu, 50. 
[20] Odimegwu, I. (2007) African Communalism and the Search for African Personhood. In: Odimegwu, I., Ed., Perspectives on African Communalism, Trafford Publishing, Victoria, British Columbia, 201-217.

[21] Ojukwu, E.O. (1989) Because I am Involved. Spectrum Publications, Ibadan.

[22] Ojukwu, E.O. (1989) Because I am Involved. Spectrum Publications, Ibadan, 3-4.

[23] Rosenfelder, M. (2015) How to Tell If You Are American. The Metaverse. http://www.zompist.com/amercult.html 